Plowman J.E., Harland D.P., Campos A.M.O., Rocha e Silva S., Thomas A., Vernon J.A, van Koten C., Hefer C., Clerens S., Almeida A.M. 2020. The wool proteome and fibre characteristics of three distinct genetic ovine breeds from Portugal. Journal of Proteomics 225: 103853.

https://doi.org/10.1016/j.jprot.2020.103853

\title{
The wool proteome and fibre characteristics of three distinct genetic ovine breeds from Portugal
}

Author links open overlay panelJeffrey E.PlowmanaDuane P.HarlandaAlexandre M.O.Campos ${ }^{\mathrm{b}}$ SeverianoRocha e SilvacAncyThomas ${ }^{\mathrm{a}}$ James AVernonaChikakovan

Koten ${ }^{\mathrm{C} C h a r l e s} \mathrm{Hefer}^{\mathrm{S}}$ StefanClerens ${ }^{\mathrm{a}}$ André M.de Almeida ${ }^{\mathrm{d}}$

Show more

Add to Mendeley

Share

Cite

https://doi.org/10.1016/i.jprot.2020.103853Get rights and content

\section{Highlights}

different genetic types of sheep (Ovis aries) have wool with different quality traits;

$\bullet$

here we study the effects the genetic type of each breed on the wool proteome and morphometric characteristics;

$\bullet$

Merino, Bordaleiro and Churro, 3 sheep types, have wools with different morphological and proteome characteristics; 
major differences were found between Merino and Churro types with respect to keratins K75 and K38;

KAPs differences in Merino vs. Churro: higher orthocortex cell type related to higher curvature in Merino.

\section{Abstract}

Wool properties and commodity value vary considerably between breeds. In Portugal, three major ovine groups exist: Churros, Bordaleiros and Merinos. This work studies the effect of the ovine genotype on the wool proteome of such groups. Wool was collected from 15 ewes/breed and genetic groups: Churra da Terra Quente (CTQ) or Churro, Serra da Estrela (SE) or Bordaleiro and Merino Branco (MB) or Merino. Proteins were extracted and subjected to label-free proteomics analysis. A total of 50 keratinous protein groups were identified in all the samples, divided into type I and II keratins and the keratin associated proteins: high-glycine-tyrosine proteins, ultra-high sulphur proteins and high-sulphur proteins. Major differences were found between MB and CTQ with respect to K75 and K38, both medullar proteins and to a lesser extent between SE and CTQ suggesting that these might be good markers for this trait in wool. Partial least squares discriminatory analysis proved MB to be readily distinguishable from the other two breeds. Further differences were noted in keratin associated protein levels between the three breeds, normally an indicator of higher levels of orthocortex and also their relationship to high curvature, high crimp fibres like Merino.

\section{Biological significance}

The ovine genetic type has strong effects on wool productivity parameters and quality traits. In this work, we compare the proteomes and the microscopical characteristics of the wool from three distinct ovine genetic types from Portugal: Merino, Bordaleiro and Churro. Important differences were found regarding keratin associated proteins and keratins K75 and K38, suggested as putative markers for quality traits in the wool proteome such as the average curvature. 


\section{Graphical abstract}
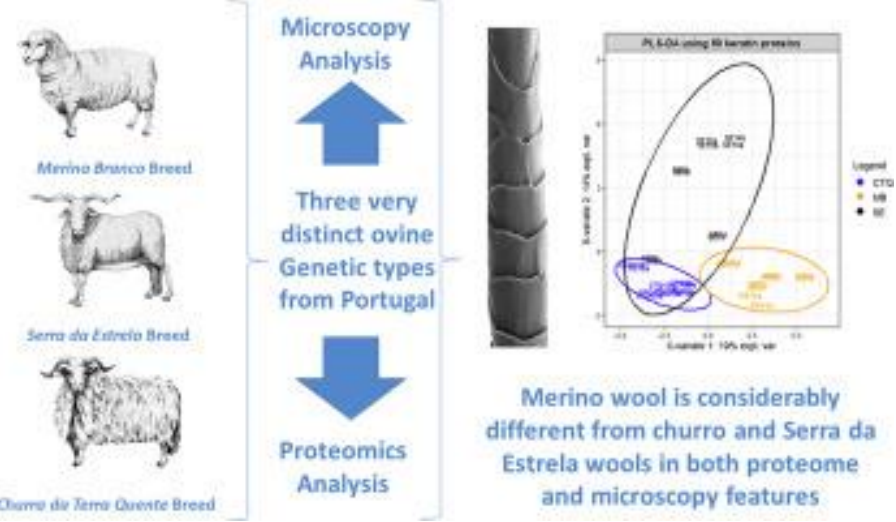

Merino wool is considerably different from churro and Serra da Estrela wools in both proteome and microscopy features

1. Download: Download high-res image (136KB)

2. Download: Download full-size image

- Previous article in issue

- Next article in issue

\section{Keywords}

Wool proteomics

Merino

Churro

Bordaleiro

\section{Introduction}

Animal fibres are valued and important commodities for textile industries worldwide. The highest value fibres include mohair and cashmere from goats (Capra hircus), alpaca (Vicugna pacos), qiviut from muskox (Ovibos moschatus) and of course wool from sheep (Ovis aries). The latter is by far the most important animal fibre, being widely used by the textile industry with an estimated 1.160 million $\mathrm{kg}$ of clean raw wool produced globally by more than 1.163 billion sheep in 2015 [1]. Wool has historically played a major role in the economies of countries such as Portugal or Spain in the 15th Century and the UK, Australia and New Zealand since the onset of the industrial revolution in the 18th Century. 
Wool is nevertheless an inconsistently applied convenient name for a quantity of fine or uniform fibres from a variety of mammals (e.g., sheep, goats, camelids and rabbits) for the textile industry. However, at an industrial scale, wool is obtained only from the ovine (Ovis aries) species. Numerous breeds are available worldwide in a plethora of production systems that include the production of wool, but also milk and meat. Ovine breeds are divided into two major categories: hair breeds and wool breeds, with the diameter of individual fibres in the latter being much finer than the former. Typically, hair sheep are characteristic of tropical regions of the world whereas wool sheep are found mostly in temperate regions. In turn, wool sheep are recognised as having three categories: coarse, mid-micron and fine wool. The textile industry uses essentially fine wool for garments and the others for the manufacture of other goods such as rugs or carpets. The present lines of domesticated sheep were derived from the mouflon (Ovis orientalis) over 10,000 years ago [2]. It is believed that initially, all domestic sheep were hair sheep, with a smaller proportion of finer under hairs, as seen in most of Europe's oldest breeds, such as those in Scandinavia that have remained unaltered since the Viking age. It is thought that the fine fleece, as found in the merino sheep, was a result of a gradual narrowing of fibres, particularly in the primary follicle.

Coupled with this, was the loss in the importance of the primary follicle, resulting in a switch in the secondary:primary follicle proportion from 1:20 to one precisely the opposite. Present evidence suggests that the fine fleece developed at some point in the later first century AD [ $\underline{3}]$.

Despite its relatively small geographical size, Portugal in SW Europe, accounts for fifteen different autochthonous sheep breeds. These, in turn can be divided into three major groups: Churro, Bordaleiro and Merino with respectively 7, 5 and 3 breeds. Churro breeds are very ancient and are believed to have remained unaltered since preRoman days. They are typically farmed in small-scale mountain production systems, being very tolerant to harsh climates and poor-quality pastures. On the contrary, Merino breeds are more recent (early medieval age) and are farmed in commercial farming systems in the southern plains, mostly in the Alentejo region. Finally, Bordaleiro breeds are mostly dairy sheep and used extensive dairy production systems in Central Portugal. Of the three types of fleece, Churro breeds produce a very coarse type of wool (over $80 \mu \mathrm{m}$ ) with long and hanging fibres whereas Merino breeds produce a high-quality fleece with a very thin $(8-25 \mu \mathrm{m})$ curly fibre. Finally, 
Bordaleiro breeds produce an intermediate type of fleece with a thickness of 25$40 \mu \mathrm{m}$ [4]. Fig. 1 shows examples of the three different breeds with their distinctive fleece and wool differences (Fig. 2). In the present production conditions in Portugal, only Merino wool has any commercial value and the industry tends to favour white fibres and devalue pigmented wool. Nevertheless, the production of certified products and the establishment of specific alternative niche markets from autochthonous breeds are growing in importance [5].
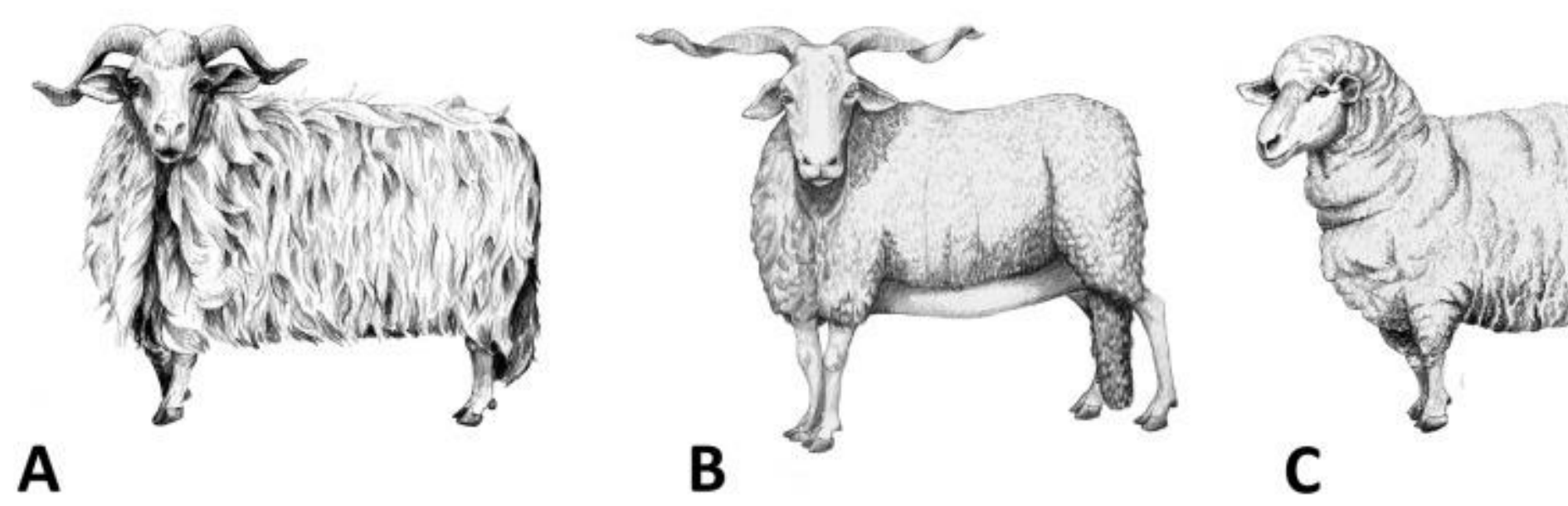

1. Download: Download high-res image (278KB)

2. Download : Download full-size image

Fig. 1. Major Portuguese Ovine groups: Churo, Bordaleiro and Merino differing in the type of fleece. Representative breeds used in this study are shown here: Churra da Terra Quente (A), Serra da Estrela (B) and Merino Branco (C). 


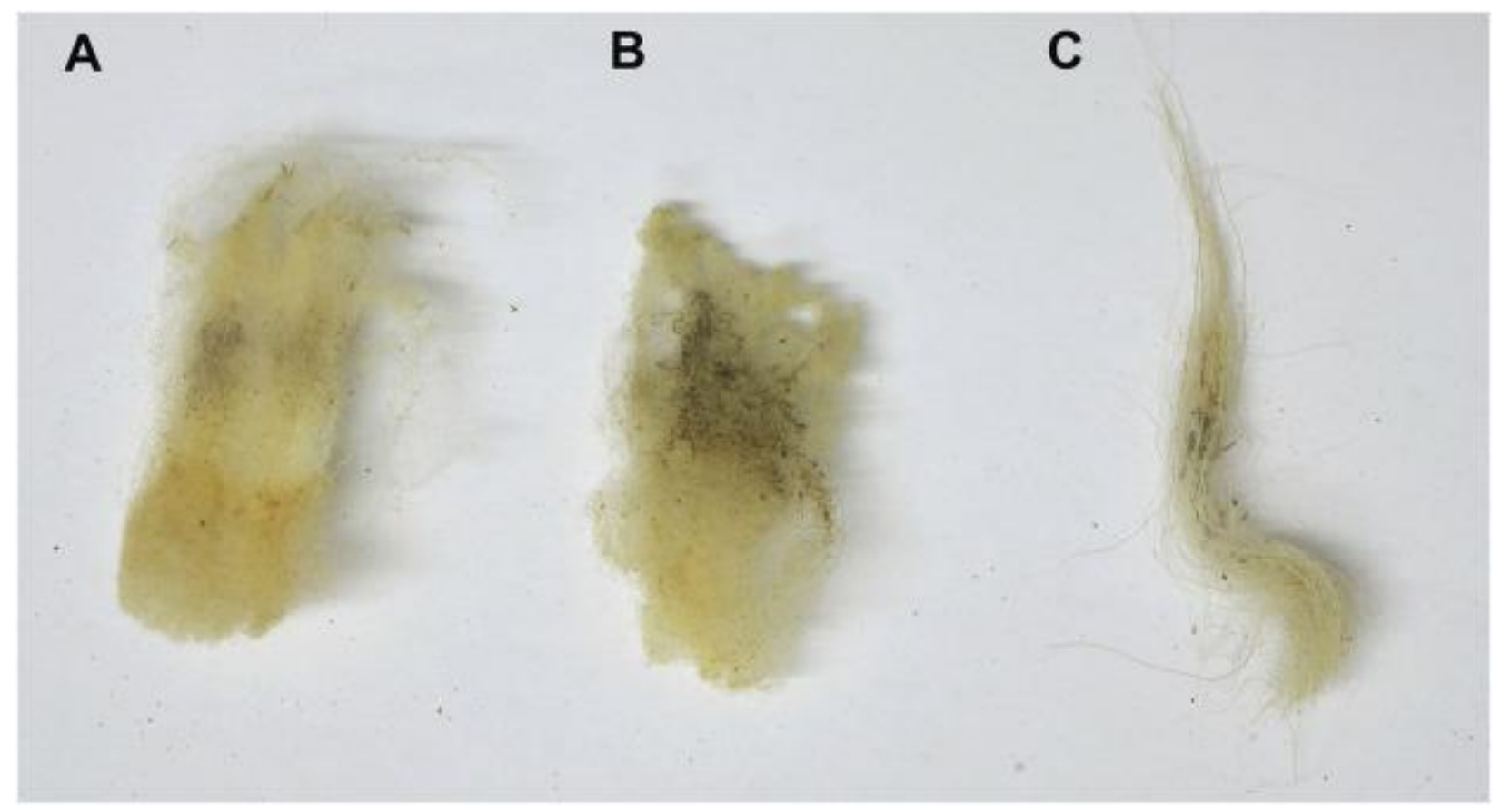

1. Download: Download high-res image (316KB)

2. Download: Download full-size image

Fig. 2. Samples of wool staples from: (A) Merino Branco (MB), (B) Serra da Estrela (SE) and (C) Churra da Terra Quente (CTQ).

Proteomics is a set of techniques of growing importance in the field of animal and veterinary sciences [] , albeit with some limitations, particularly when making comparisons to model species [7]. Its use has been demonstrated in numerous areas, from meat science and technology [] ] to the study of tick-borne disease virulence [9] or the goat mammary gland physiology [10]. During the last two decades, proteomics has been extensively used to study the wool protein composition and its relation to quality. Indeed, since the earlier works [11], numerous studies have been published on this aspect. These include the proteome of the wool cuticle [12], the effect of nutrition on the merino wool proteome [13] or the wool fibre morphogenesis [14]. The subject has furthermore been extensively reviewed [15] and readers are directed to it for further information.

Interestingly, fibre/wool proteomics has seldom been used to study species and breed differences. Indeed, Thomas and co-workers conducted the first interspecies comparison of morphology, ultrastructure, and proteome of keratin fibres in different mammal species: sheep, goat (mohair), rabbit and alpaca [16]. More recently, proteomics has been used to differentiate sheep from goat fibres [17]. However, 
concerning breed comparison studies, to the best of our knowledge, very few studies seem to be available. Our research teams have recently published a study that contrasted the differences between the white and black merino breeds, highlighting differences mostly at the level of high-sulphur proteins or HSPs and high-glycinetyrosine proteins or HGTPs [5].

The objective of this study is to compare the three different ovine types with respect to their wool quality traits, namely fibre diameter and curvature, as well as the protein abundance patterns and for this a label-free approach was adopted [18]. Our ultimate goal is that of understanding the effects of protein composition on wool quality traits in three very diverse types of sheep that are in turn representative of the major sheep populations existing in Southern Europe and, hence, what consequences this might have for the conventional and alternative textile industries. Given that proteins make up $98 \%$ of the total fibre content by weight [19] and $85 \%$ of these are the keratinous proteins [20] we chose to focus on the keratin proteome in this study.

\section{Materials and methods}

\subsection{Animals and sample collection}

Methodologies were adapted from Plowman and co-workers [5]. In this study, we sourced Merino (Merino Branco breed) wool samples from commercial farms in the Évora District in Alentejo region (Southern Portugal), Bordaleiro (Serra da Estrela breed) wool from the Coimbra District in the Beira Interior region (Central Portugal) and Churro (Churra da Terra Quente breed) wool from the Vila Real District in the Trás-os-Montes region (Northeast Portugal). These were randomly obtained from ewes shorn in the shearing season in May-June 2018. All the animals were raised under an extensive management system based on natural pastures. The age of the animals ranged between 3 and 6 years, had a similar body condition score (2.5 to 3.5 in a scale of 1 to 5) and were registered in the different herd books, managed by the different Breeders Associations for each breed. An area of approximately $100 \mathrm{~cm}^{2}$ was shorn from the left hind quarters of each animal and kept in paper envelopes until further proteomic analysis. A total 5 different animals per breed were sampled, with one wool sample per animal. 


\subsection{Wool diameter and curvature determinations, scouring, protein extraction and quantification}

The mean fibre diameter and the curvature of the wools were determined with an optical fibre diameter analyser OFDA 2000 (BSC electronics, Ardross, WA, Australia) at SGS New Zealand Ltd. (Timaru, New Zealand) following the manufacturer's instructions. This involved scouring five staples from each animal, which were then subsampled before being cut into $2 \mathrm{~mm}$ snippets. The results are reported as the mean fibre diameter and curvature of the five animals from each breed.

Extraneous dirt and sebum was removed from the wool fibres from each animal by washing first with $0.15 \%$ Teric GN9 twice for 2 min each time at $60{ }^{\circ} \mathrm{C}$, followed by washing twice with water for $2 \mathrm{~min}$ each time at $60{ }^{\circ} \mathrm{C}$. The fibres were air dried overnight and then washed twice with dichloromethane, twice with ethanol and twice with water for $30 \mathrm{~s}$ each time before being snipped to approximately $1 \mathrm{~mm}$ in length with scissors. Four $10 \mathrm{mg}$ scoured wool samples per breed were shaken for $18 \mathrm{~h}$ with $1 \mathrm{ml}$ of $7 \mathrm{M}$ urea, $2 \mathrm{M}$ thiourea, $50 \mathrm{mM}$ tris buffer and $50 \mathrm{mM}$ dithiothreitol at $\mathrm{pH}$ 9.3. The wool protein extracts were quantitated using a 2DQuant kit (GE Healthcare Lifesciences, Auckland, New Zealand) following the manufacturer's instructions.

\subsection{Label free quantitative (LFQ) proteomics analysis}

A total of $150 \mu \mathrm{g}$ of protein from each sample was taken and precipitated using methanol/chloroform. The precipitate was resuspended in $60 \mu \mathrm{L}$ of $0.1 \mathrm{M}$ ammonium bicarbonate. The protein was chemically reduced by agitation with $20 \mu \mathrm{L}$ of $100 \mathrm{mM}$ tris(2-carboxyethyl) phosphine at $56^{\circ} \mathrm{C}$ for $45 \mathrm{~min}$. The proteins were then alkylated by the addition of $20 \mu \mathrm{L}$ of $150 \mathrm{mM}$ iodoacetamide, with agitation at room temperature in the dark for $30 \mathrm{~min}$. Sequencing grade trypsin (trypsin to protein ratio 1:50) was added, and the digestion mixture was incubated overnight at $37{ }^{\circ} \mathrm{C}$ in the presence of $10 \%$ acetonitrile. The digests were desalted using Pierce ${ }^{\text {TM }} \mathrm{C}-18$ spin columns (Thermo Scientific, USA), dried down and stored at-20 ${ }^{\circ} \mathrm{C}$ until further use. Before mass spectrometric analysis, the samples were resuspended in $40 \mu 10.1 \%$ formic acid. The resuspended digest was further diluted five times prior to injection into the mass spectrometer. 
LC-MS was performed on a nanoflow Ultimate 3000 UPLC (Dionex) coupled to an Impact HD mass spectrometer equipped with a CaptiveSpray source (Bruker Daltonik, Bremen, Germany). For each sample, $1 \mu \mathrm{L}$ of the sample was loaded on a C18 PepMap100 nano-Trap column (300 $\mu \mathrm{m}$ ID x 5 mm, $5 \mu \mathrm{m} 100 \AA$ ) at a flow rate of $3000 \mathrm{nl} / \mathrm{min}$. The trap column was then switched in line with the analytical column ProntoSIL C18AQ (100 $\mu \mathrm{m}$ ID x $150 \mathrm{~mm} 3 \mu \mathrm{m} 200 \AA$ ). The reverse phase elution gradient was from $2 \%$ to $20 \%$ to $45 \%$ B over $60 \mathrm{~min}$, total $85 \mathrm{~min}$ at a flow rate of $1000 \mathrm{nl} / \mathrm{min}$. Solvent A was LCMS-grade water with $0.1 \%$ Formic acid; solvent B was LCMS-grade ACN with $0.1 \%$ FA.

To profile protein expression patterns, the analytes were detected via MS-only mode in positive ion mode, with a mass range between 130 and $2200 \mathrm{~m} / \mathrm{z}$ and a sampling rate of $2 \mathrm{~Hz}$. All samples were measured in duplicate. To link the expression levels with identifications, a pool per breed was created by combining $5 \mu$ of every sample digest, and these pools were run via LC-MS/MS in triplicate in data-dependent acquisition mode, with an acquisition speed of $2 \mathrm{~Hz}$ in MS and 1-20 Hz in MS/MS mode depending on precursor intensity. Ten precursors were selected in the $\mathrm{m} / \mathrm{z} 350$ 1200 range, with preference for doubly or triply charged peptides. The analysis was performed in positive ionization mode with a dynamic exclusion of $60 \mathrm{~s}$. Following the LC-MS run, the QTOF data were searched using Peaks Studio 8.5 (Bioinformatics Solutions Inc). The raw data were refined by a built-in algorithm and protein/peptides were identified using the following parameters: a precursor mass tolerance of $10 \mathrm{ppm}$; fragment mass tolerance of $0.05 \mathrm{Da}$, a taxonomy of Ovis aries with an in house Sheep_uniprot_ovine_2016_10_plus_keratins database. This database was derived from the Uniprot 2016_10 database, augmented by 54 AgR sequences from EST contigs, annotated by BLAST searching against the NCBI database and keratin sequences from the NCBInr non-redundant database. Trypsin was chosen as the proteolytic enzyme and up to 2 miscleavages were allowed. Carbamidomethyl (C) was specified as fixed modification, and oxidation (M), deamidation (NQ) and phosphorylation (STY) were chosen as variable modifications. A false discovery rate (FDR) of $1 \%$ at the peptide-spectrum match (PSM) level was used for peptide identification in Peaks. In addition, the Peaks post-translational modification (PTM) A-score was set to 50, de novo only ALC > 80\% and only 
proteins with a minimum of 1 unique peptide identification were included. As the keratin-family of proteins is known to have highly similarly in protein sequences, the quality of identification of all peptides was checked manually. Quantification of proteins is performed via the Label-free workflow in Peaks with following settings: a mass error tolerance $15 \mathrm{ppm}$, a retention time shift of 2 min and a FDR threshold of $1 \%$ for peptides. Protein quantification was estimated by using the area under the curve values of the top three unique peptides per protein.

\subsection{Statistical analysis}

For the purposes of statistical analysis, the three breed groupings were used, as defined by their particular breed names: Merino Branco (MB) wool, Serra da Estrela (SE) wool and Churra da Terra Quente (CTQ) wool. Results for wool diameter and curvature were compared using ANOVA-single-factor proceedings.

The keratin proteome analysis was performed in a two-fold way: First, to detect differentially expressed proteins, quantitative protein values were compared between sheep breeds. This protein-by-protein comparison was made with a linear mixed model (LMM) analysis. Each LMM analysis modelled correlation between duplicated measurements of each sample as a random effect, and breed effects (factor with three levels) as fixed effects. All LMM analyses were carried out with the statistical software R, using the lmer() function of the lme4 package.

Second, to allow visualisation of the protein profiles per sample and breed, partial least squares discriminatory analysis (PLS-DA) was carried out on the keratin-family subproteome. Quantitative protein data were scaled and centred prior to subjecting the dataset to partial least square analysis using the plsda() method from mixOmics (version 6.9.2) in $\mathrm{R}$ (version 3.6.1). The results were plotted using plotIndiv() from the same package. The PLS-DA loadings from the pairwise comparison between breeds were exported and used to generate the loadings and abundance plot using R.

\subsection{Transmission electron microscopy (TEM)}

Our research group has extensively studied Merino type wools using transmission electron microscopy $[\underline{16}, \underline{21}, \underline{22}]$. Given the descriptive nature of these studies, we 
found it would be redundant to conduct in the Merino Branco breed. As such, we have focused on CTQ and SE. Wool samples from two CTQ and two SE animals were scoured with detergent (Teric GN9) and then heptane. Processing using three cycles of en bloc reduction-osmication is described previously [21], and only brief methods are given here. The fibres were chemically reduced (2-mercaptoethanol) then stained with $1 \%$ osmium tetroxide (repeated thrice). Samples were then stained with $2 \%$ uranyl acetate, vacuum dehydrated and embedded in procure 812-araldite epoxy resin. Ultrathin (90 nm thick) sections were cut using an Ultracut UCT ultramicrotome (Leica, Wetzlar, Germany) fitted with a $45^{\circ}$ diamond knife (Diatome, Nidau Switzerland) and sections enhanced with $2 \%$ UA (1 min) and $0.2 \%$ lead citrate (20 s). Sections were examined using a FEI (Hillsboro, OR, USA) Morgagni 268D transmission electron microscope, and micrographs captured using a Tengra digital camera (Emsis, Muenster, Germany) mounted below the phosphorus screen.

\section{Results}

\subsection{Macroscopy and microscopy studies}

There were considerable differences in appearance between fibres from the three breeds and this was reflected in the results from the OFDA analysis (Table 1). The CTQ fibres were notable for their coarse, straight fibres, more characteristic of kemps or guard hairs and these had the highest fibre diameter (mean of $43.8 \mu \mathrm{m}$ ) and lowest curvature (mean of $25.8 \% \mathrm{~mm}$ ) of the three breeds. At the other extreme were the MB fibres that had the lowest fibre diameter (mean of $24.4 \mu \mathrm{m}$ ) and highest curvature (mean of $115.2^{\circ} / \mathrm{mm}$ ). The SE fibres lay in between these with a mean fibre diameter $27.2 \mu \mathrm{m}$ and mean curvature of $73 \% \mathrm{~mm}$. On the basis of the $p$-value SE fibres are significant different from CTQ fibres and MB fibres significantly different from CTQ fibres on the basis of both their mean fibre diameter and curvature. In contrast, MB are only significantly different from SE on the basis of their curvature.

Table 1. Mean fibre diameter and curvature of the individual sheep from the study along with the $p$-values. Statistically significant differences are marked with an asterisk.

\section{Ovine Breed Type}

Churro

$43.8 \pm 13.4$

Mean fibre diameter $(\mu \mathrm{m}) \pm \mathrm{SD}$
Curvature $(\% / \mathrm{mm}) \pm \mathrm{SD}$ 
Ovine Breed Type

Bordaleiro

Merino

Bordaleiro vs Churro

Merino vs Churro

Merino vs Bordaleiro
Mean fibre diameter $(\mu \mathrm{m}) \pm S D$

$27.2 \pm 5.0$

$24.4 \pm 4.8$

$0.049 *$

$0.029 *$

0.396
Curvature $(\% / \mathrm{mm}) \pm$ SD

$73.0 \pm 10.90$

$115.2 \pm 10.66$

$<0.001^{*}$

$<0,001^{*}$

$<0.001^{*}$

Staples of cleaned CTQ and SE wool differed macroscopically from one another (Fig. 3). Both CTQ and SE contain guard hairs as well as underhairs. In CTQ samples the guard hairs were prominent and underhairs were very short (Fig. 3A).

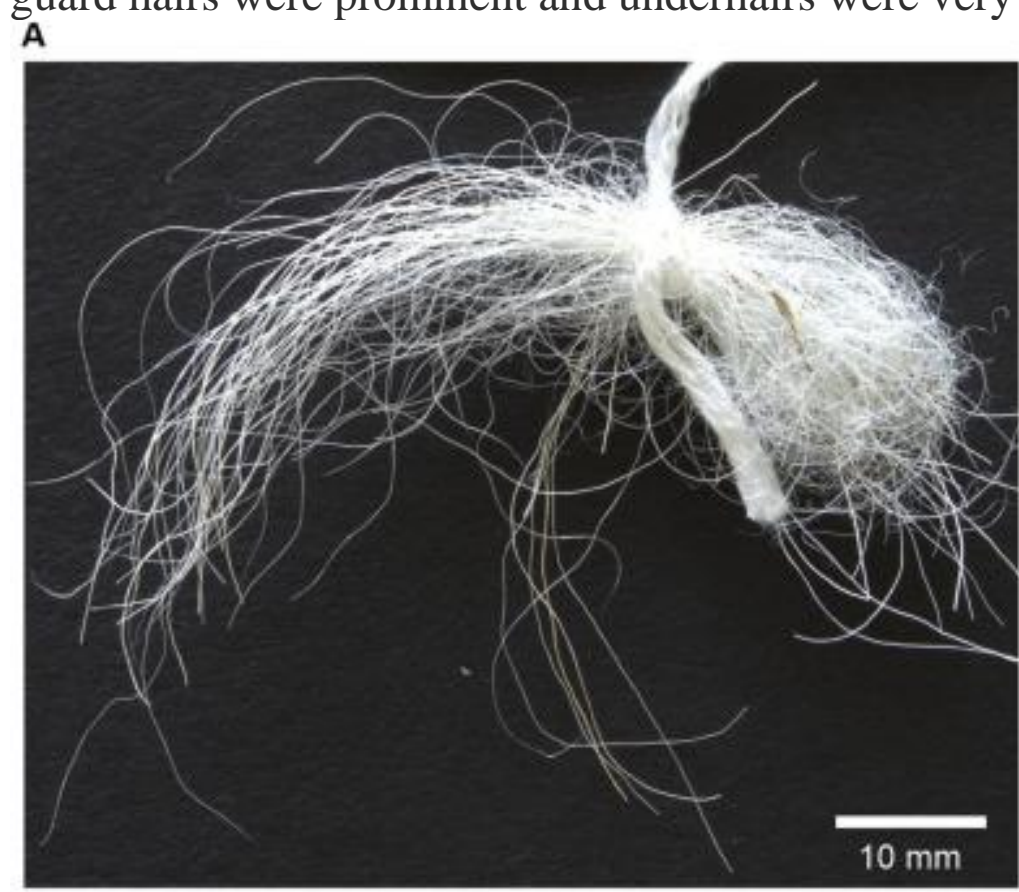

B

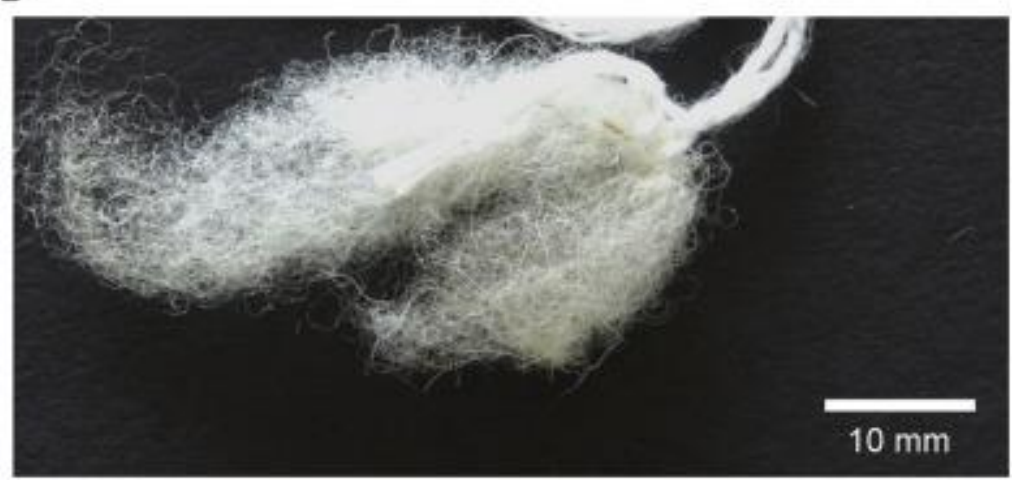


1. Download : Download high-res image (492KB)

2. Download: Download full-size image

Fig. 3. Photographs of scoured staples of (A) CTQ and (B) SE wool fibres. In both cases the tip is left.

In CTQ samples, four underhairs examined by transmission electron microscopy (TEM) had elliptical profiles (Fig. 4A). These underhairs were not medullated and had distinctly differentiated orthocortices and paracortices (Fig. 4B) that each had a bilateral arrangement bisecting the long axis of their elliptical profiles (Fig. 4A). Guard hairs in the CTQ sample included those with a diameter less than some underhairs (Fig. 4C) and also many of much higher diameter (kemps). Cortical cell types in CTQ guard hairs contained orthocortex and paracortex, and cells that were intermediate (sometimes called heterocortex). Typically the fibril-matrix structure from cells that resembled paracortex at lower magnification (Fig. 4D) was composed of macrofibrils with low-intensity double-twist structure when examined at high magnification (Fig. 4E). 

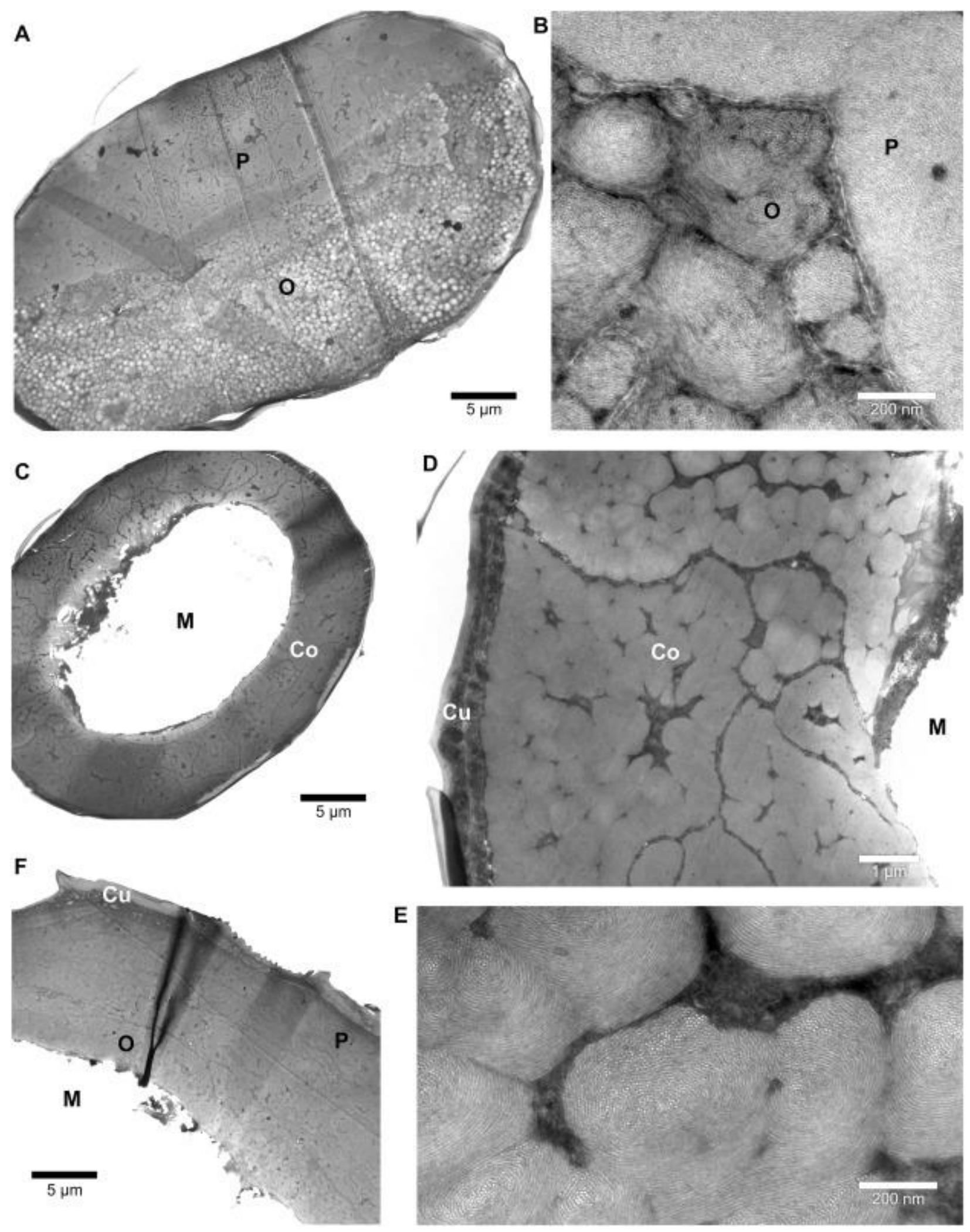

1. Download: Download high-res image (2MB)

2. Download: Download full-size image 
Fig. 4. Transmission electron micrographs of cross-sections of CTQ underhairs and guard hairs. A. Underhair. B. High magnification of underhair cortical cells at fibre centre. C. Small guard hair with central medulla. D. Cell types within small guard hair. E. High magnification of cortex cell of small guard hair. F. Part of a high-diameter guard hair. Abbreviations: Co, cortex; $\mathrm{Cu}$, cuticle; $\mathrm{M}$, medulla; $\mathrm{O}$, orthocortex; $\mathrm{P}$, paracortex.

Five underhairs from SE samples examined by TEM were circular in profile and had clearly defined orthocortices and paracortices in a bilateral organisation (Fig. 5A). A high level of differentiation between orthocortex and paracortex was clearly visible in underhairs at cortex (Fig. 5B) level and at high magnification (Fig. 5C). The organisation of smaller (Fig. 5D) and larger (Fig. 5E) guard hairs was similar to that of hairs from CTQ wool. 

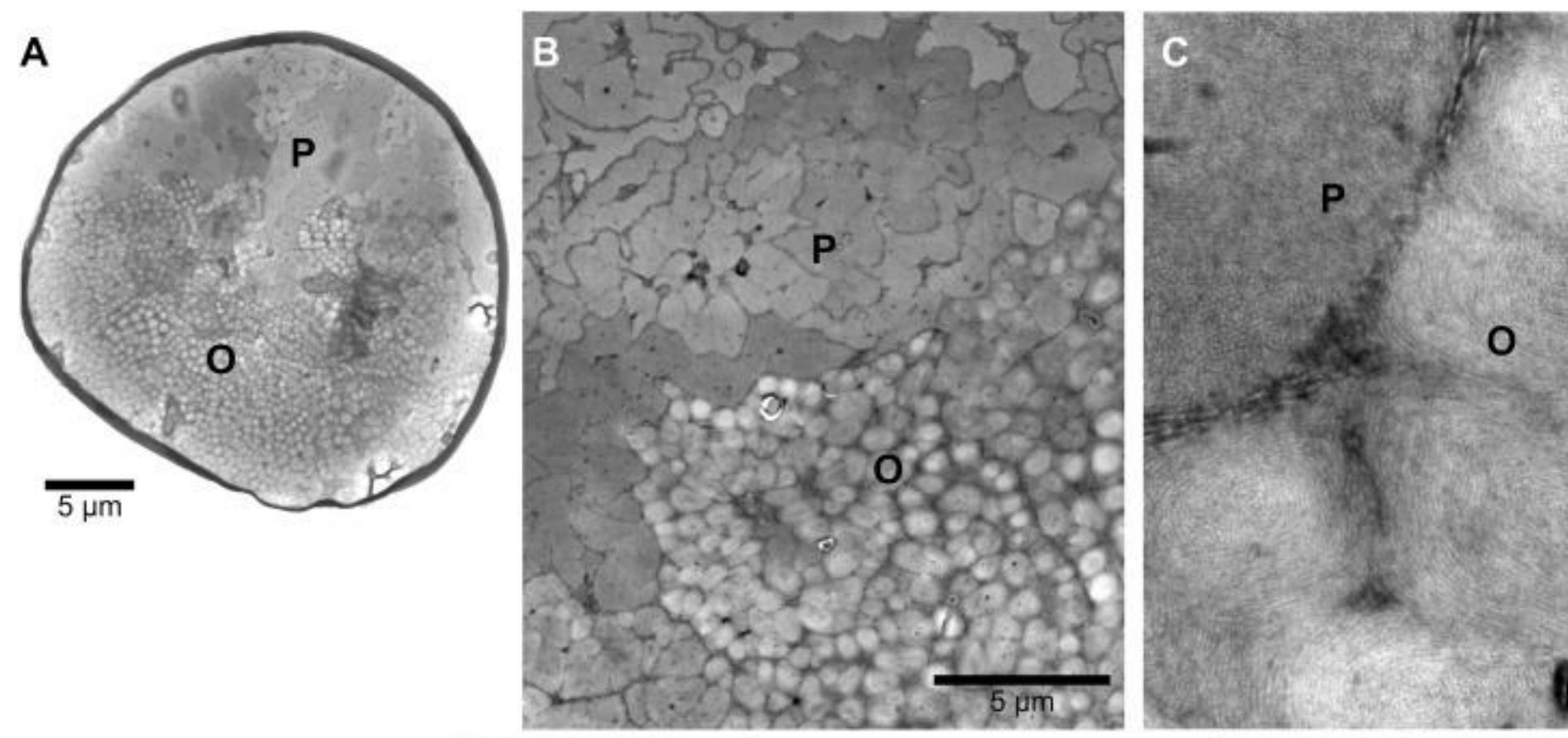

D
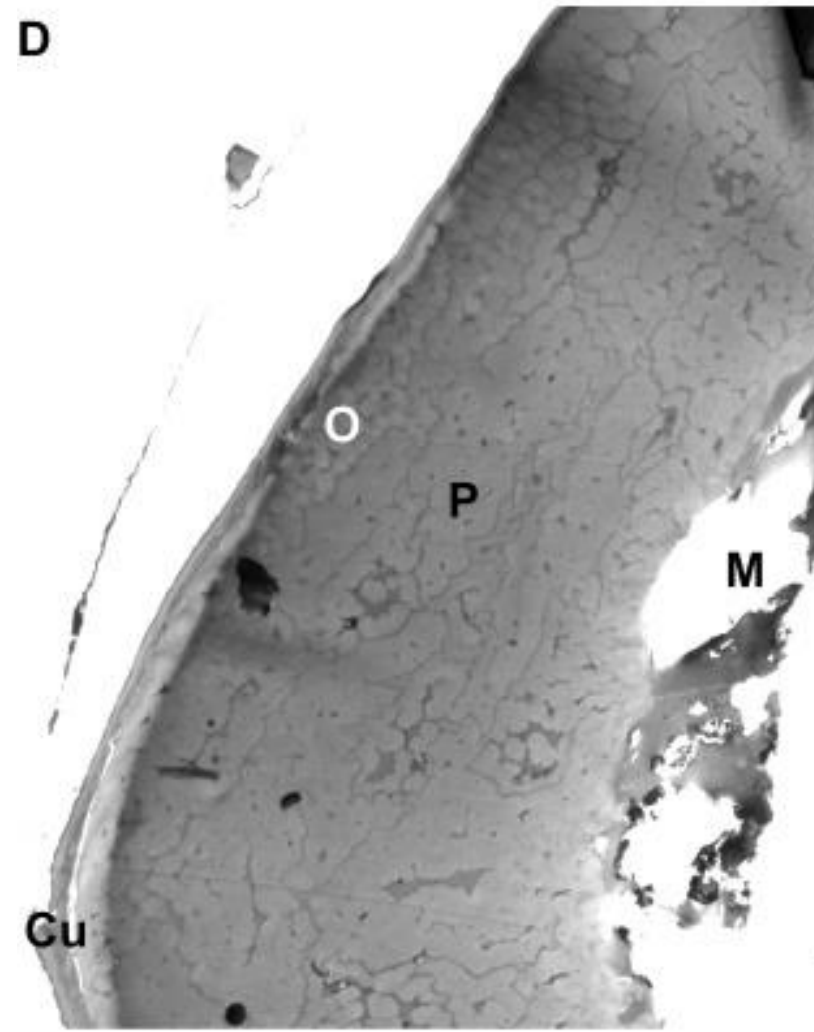
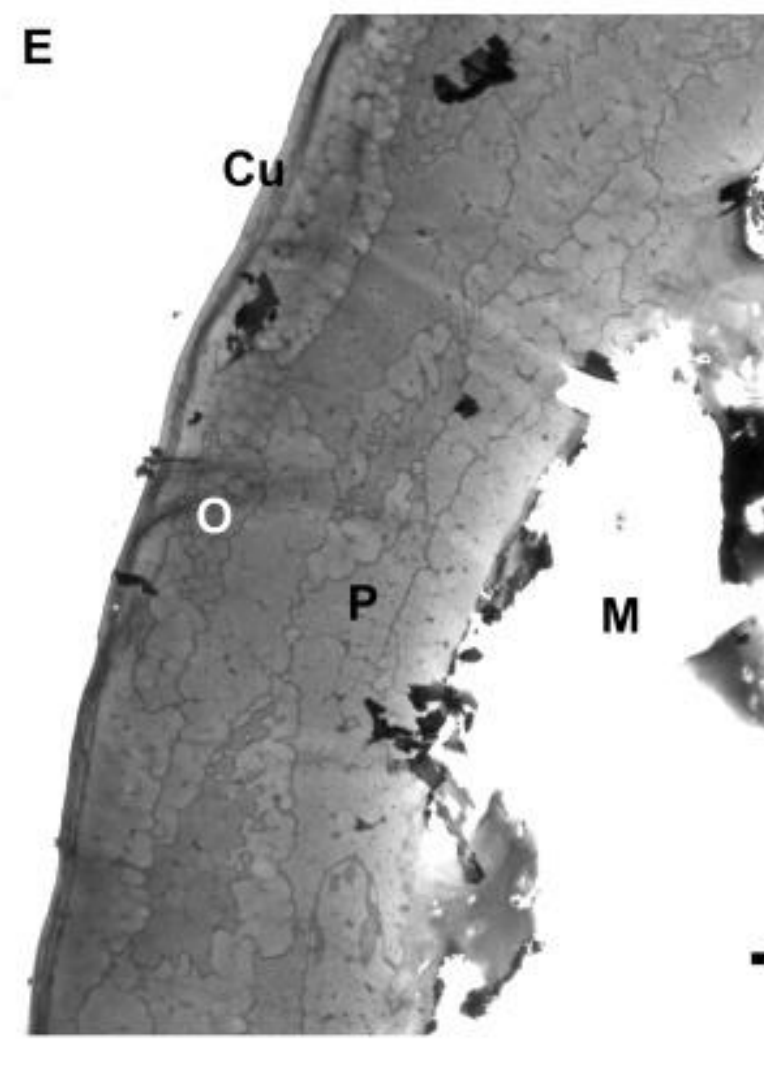

1. Download: Download high-res image (2MB)

2. Download: Download full-size image

Fig. 5. Transmission electron micrographs of SE underhairs and guard hairs. A.

Underhair. B. Clearly defined orthocortex and paracortex in an underhair. C. High- 
magnification of underhair cortical cells at fibre centre. D. Part of a smaller guard hair. E. Part of a larger guard hair. Abbreviations: $\mathrm{Co}$, cortex; $\mathrm{Cu}$, cuticle; $\mathrm{M}$, medulla; $\mathrm{O}$, orthocortex; P, paracortex.

\subsection{Proteomics analysis}

Quantitative analysis of keratin proteins in hair fibres has a number of challenges not the least of which is the high degree of homology between proteins in the various families, which can be as high as $92 \%$ between the four major trichocyte (hair) type I keratins [23]. One other issue is the diversity in the keratin and keratin associated proteins, there being nine type I keratins, seven type II keratins and a total of 89 keratin associated proteins, the latter generally subdivided into three classes, HSP, ultra-high sulphur protein and HGTP. A further complication is the high degree of polymorphism found in the KAPs, with three examples of length polymorphism being evident in KAP1.1 and nine polymorphisms in each of KAP1.2, KAP1.3 and KAP1.4. The KAP4 family is notable for having 27 members made up of combinations of two repeat sequences in proteins of different lengths, making unique identification of every protein in this family difficult. Keratins expressed only in the cuticle, including $\mathrm{K} 32$, K82 and K84, are less readily extractible compared to those in the cortex, while those like the KAP5 family found only in the a-layer, a type of cornified cell envelope, can only be extracted by approaches that cleave cysteine peptide bonds [24]. For these reasons it is highly unlikely that all keratin and KAP proteins can be identified in any one fibre sample and the high degree of homology among the various keratin protein families limits the number of unique peptides available for quantitative purposes.

A total of 206 proteins within 78 protein groups were identified in the wool samples; where a protein group is defined by Peaks as highly similar sequences which were assigned to that group based on observation of the same set of identifying peptides (or subsets thereof) in the LC-MS/MS run [25]. Of these 78 protein groups, 50 were matched to keratinous proteins; specifically 4 epithelial keratins, 16 trichocyte keratins and 30 keratin associated proteins (KAPs). Among the non-keratinous matches were actin, vimentin, galectin, four histones, a $60 \mathrm{~S}$ ribosomal protein, UDPglucuronytransferase and peptidyl-prolyl-cis-trans-isomerase. Full proteomics results are presented in detail in supplementary materials 1 and 2. For the major four cortical 
Type I and four Type II trichocyte (hair) keratins sequence coverage was found to range between 84 and 94\%, while cuticular keratins have lower sequence coverage, for K32 only $30 \%$. At least half of the KAPs had sequence coverages of over $60 \%$, with KAP4.5 and KAP16.2 at 100\% coverage, while KAP9.2 had a sequence coverage of $25 \%$ and KAP15.1 only $19 \%$. In contrast the non-keratinous proteins had very low sequence coverages, for instance Histone $\mathrm{H} 2 \mathrm{~A}$ had a sequence coverage of $7 \%$ and ubiquitin a coverage of $12 \%$, both with only one peptide identified.

The LFQ analysis was confined to the quantitative data for the keratins because keratins and KAPs are the primary structural components of wool fibres [26, $\underline{27}]$ and quantitative 2-dimensional electrophoretic studies have shown a strong association between changes in these proteins and changes in internal fibre morphology [28]. When looking at the protein profiles of these keratin subfamily of each of the samples, MB could be discriminated from the other two breeds using partial least squares discriminatory analysis (PLS-DA). (Fig. 6). In contrast, there was a slight overlap between the SE and CTQ breeds with the latter appearing almost as a subset of the SE breed.

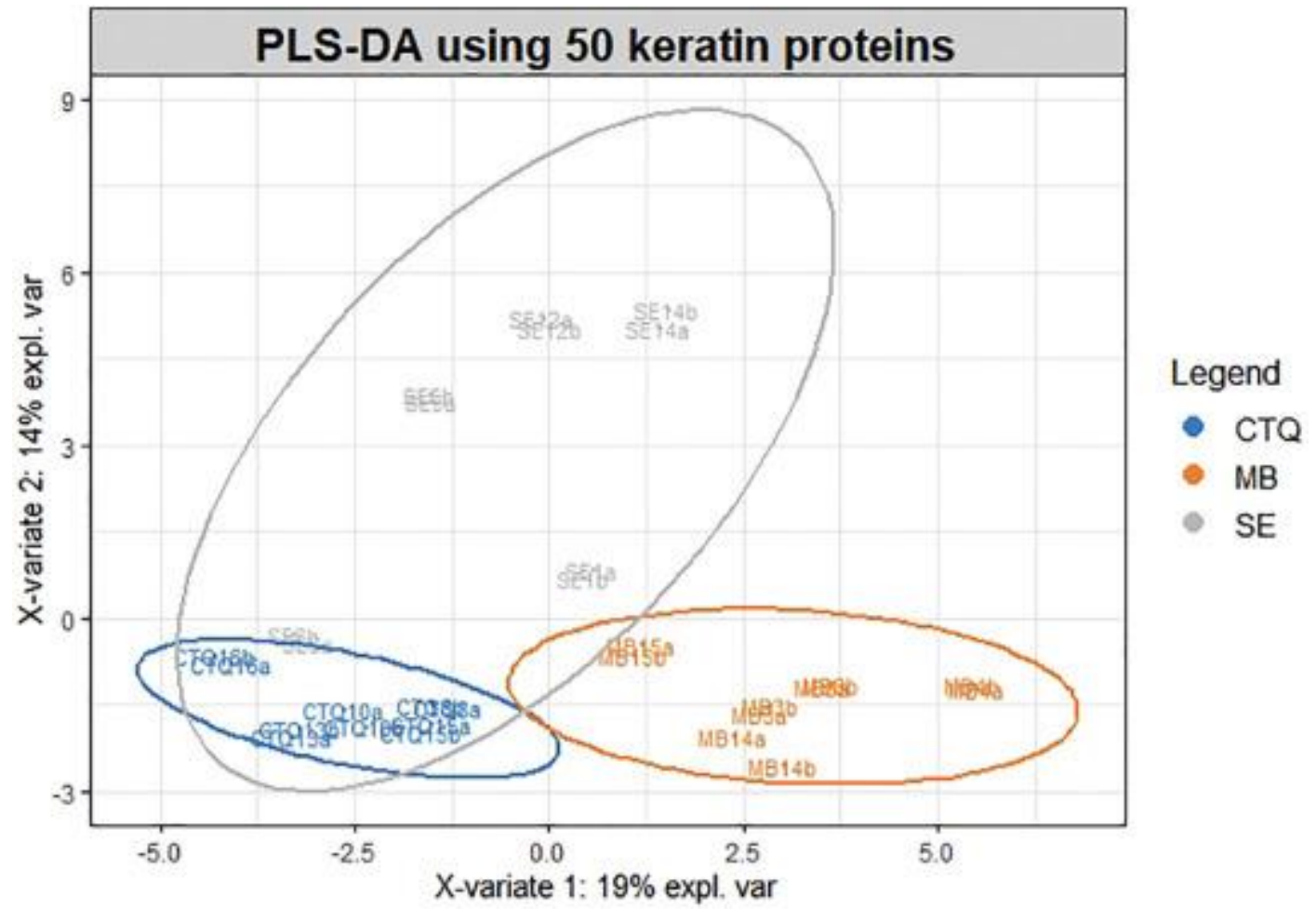

1. Download: Download high-res image (170KB)

2. Download: Download full-size image 
Fig. 6. PLS-DA analyses of the three breeds using 50 keratin and keratin associated proteins. The ellipses represent the $95 \%$ confidence level of the discrimination algorithm. PLS-DA analyses indicated a separation of the MB samples from the SE and CTQ samples. The CTQ samples clustered completely within the predicted area of the SE samples. Samples SE8a and SE8b clustered together with the CTQ samples.

Differential abundance levels for each of the keratin and keratin associated proteins is presented in Fig. 7(B). Seven proteins were identified as differentially abundant $(\mathrm{P}<.05$ from LMM) in the comparison between CTQ and MB, and three proteins between the MB:SE and CTQ:SE comparisons. One protein of high importance to the discrimination between $\mathrm{MB}$ and CTQ was K75v1, the fold change being 23.9-times for CTQ over MB ( $P=.004$ from LMM analysis). In addition to these proteins, other keratins show differential abundance between the three breeds, K35 showing increased abundance in CTQ as opposed to MB $(P=.044)$. 
A

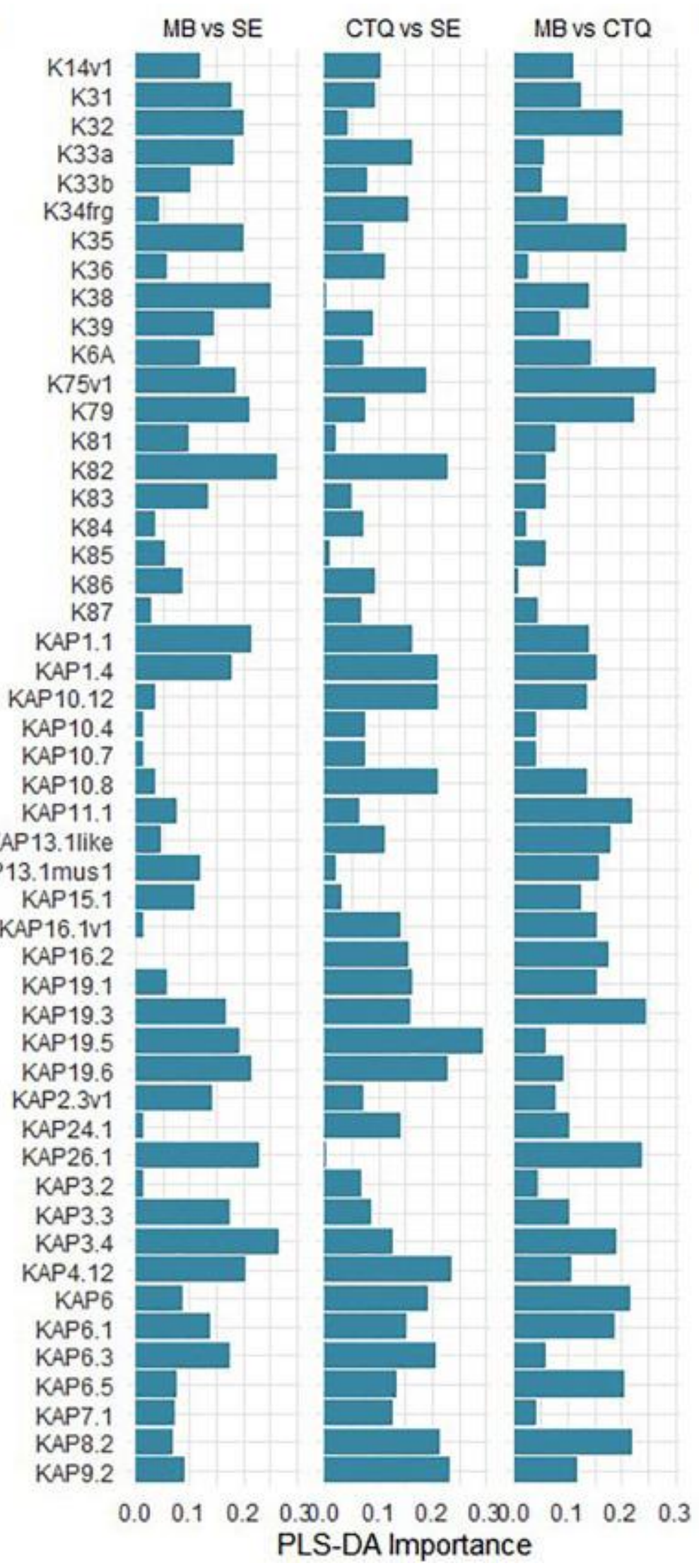

B

$\mathrm{K} 14 \mathrm{v} 1$
$\mathrm{~K} 31$
$\mathrm{~K} 32$
$\mathrm{~K} 33 \mathrm{a}$
$\mathrm{K} 33 \mathrm{~b}$
$\mathrm{~K} 34 \mathrm{frg}$
$\mathrm{K} 35$
$\mathrm{~K} 36$
$\mathrm{~K} 38$
$\mathrm{~K} 39$
$\mathrm{~K} 6 \mathrm{~A}$
$\mathrm{~K} 75 \mathrm{~V} 1$

K79

K81

K82

K83

K84

K85

K86

K87

KAP1.1

KAP1.4

KAP 10.12

KAP 10.4

KAP 10.7

KAP 10.8

KAP11.1

KAP13.1like

KAP13.1mus1

KAP15.1

KAP16.1v1

KAP16.2

KAP19.1

KAP19.3

KAP 19.5

KAP19.6

KAP2.3V1

KAP24.1

KAP26.1

KAP 3.2

KAP 3.3

KAP 3.4

KAP4.12

KAP6

KAP6.1

KAP6. 3

KAP 6.5

KAP7.1

KAP8.2

KAP9.2

\begin{tabular}{|c|c|}
\hline \multirow[t]{2}{*}{ MB:SE } & CTQ:SE \\
\hline & 2.25 \\
\hline-4.66 & -1.71 \\
\hline-1.91 & 1.12 \\
\hline 1.47 & 1.34 \\
\hline-1.19 & -1.12 \\
\hline-1.05 & -1.21 \\
\hline-2.16 & 1.23 \\
\hline-1.06 & -1.09 \\
\hline-10.62 & 1.26 \\
\hline \multirow{2}{*}{-1.19} & -1.09 \\
\hline & -1.5 \\
\hline-10.32 & 2.32 \\
\hline-1.59 & 1.14 \\
\hline-1.08 & -1.02 \\
\hline $1.4 *$ & $1.35 *$ \\
\hline-1.1 & -1.04 \\
\hline-1.21 & -1.38 \\
\hline-1.03 & 1.01 \\
\hline 1.09 & 1.1 \\
\hline-1.02 & -1.08 \\
\hline-10.22 & -2.68 \\
\hline-3.97 & -5.19 \\
\hline 1.05 & -1.76 \\
\hline 1.17 & -1.14 \\
\hline 1.17 & -1.14 \\
\hline 1.05 & -1.76 \\
\hline-1.13 & 1.29 \\
\hline 1.26 & -1.04 \\
\hline 1.36 & -1.07 \\
\hline 1.09 & -2.65 \\
\hline 1.01 & -2.66 \\
\hline 1.24 & -1.93 \\
\hline 1.54 & -1.66 \\
\hline 2.07 & $2.45 *$ \\
\hline 2.38 & $3.4 *$ \\
\hline 1.66 & 1.11 \\
\hline 1.34 & -1.44 \\
\hline $1.49 *$ & -1 \\
\hline-1.02 & -1.13 \\
\hline-2.01 & -1.28 \\
\hline$-2.55 *$ & -1.41 \\
\hline 1.27 & -2.22 \\
\hline 1.49 & -1.62 \\
\hline-2.21 & -2.51 \\
\hline 1.41 & \\
\hline-1.32 & -1.58 \\
\hline 1.15 & -1.92 \\
\hline-1.42 & -2.95 \\
\hline
\end{tabular}


1. Download: Download high-res image (1MB)

2. Download: Download full-size image

Fig. 7. Discriminant analyses contribution (A) and protein level abundance (B) of the 50 keratin and keratin associated proteins for each pairwise breed comparison. The fold change ratio for the individual proteins in (B) between breeds are indicated within each block. Negative fold changes are in blue and positive fold changes in green/yellow/red, the intensity of the colour being a measure of the distance of the fold change from unity. Missing values indicate that one or more breeds had no abundance measurement for the specified protein in any of the samples. Significant fold changes are indicated with an asterisk $(P<.05$ from LMM). (For interpretation of the references to colour in this figure legend, the reader is referred to the web version of this article.)

Among the fold changes between breeds, the HGTPs, KAP6.1, KAP19.1 and

KAP19.3 were found in higher amounts in MB than both SE and CTQ, and there was also more of these proteins in SE than CTQ ( $P=.042$ for KAP6.1 MB vs. CTQ and $P=.011$ for KAP19.3 MB vs. CTQ, all others $P>.05)$. In addition KAP8.1 and KAP8.2 $(P=.021$ for KAP8.1 and $P=.025$ for KAP8.2) were found in higher amounts in MB vs CTQ (Supplementary material 3). It is important to mention that large quantification variations were seen for some proteins measured among replicates (median $\mathrm{CV} \%>50 \%$ for all three types of samples analyzed). Such fact must be taken into account when interpreting data.

\section{Discussion}

Transmission electron microscopy suggests that CTQ and SE wool contain a similar cast of hair types, underhairs (wool) and various diameter guard hairs, higher by comparison to those normally found in Merino breeds. Within such hair types there is much similarity in fibre ultrastructure with the primary difference being in the size and elongated cross-section profile of the underhairs from CTQ sheep. While the SE underhairs, which have a more circular cross-section, are similar in organisation to other fine wools, for example, from commercial merino sheep, the CTQ underhairs are much higher diameter.

The underhairs from CTQ are unusual for a high-diameter wool fibre because they contain exclusively highly-differentiated cortical cell types with no intermediate types (Fig. 4A and B). Orthocortical cells in CTQ contain only small, well-separated 
macrofibrils and paracortical macrofibrils, that are highly fused to one another and have negligible levels of filament twist (i.e., close to zero double-twist intensity). It has been observed in other breeds that as fibre diameter increases there is a tendency for both paracortical and orthocortical cells to increasingly contain macrofibrils of ambiguous structure [[28], [29], [30]]. Often these intermediate forms contain regions of strict hexagonal filament packing and were called mesocortex [28].

CTQ guard hairs were different from underhairs because they often contain intermediate forms of macrofibril (i.e., low double-twist intensity) (Fig. 4D and E). Diameter plays an important role in wool structure and it is often difficult to address the question of whether a fibre's cortical organisation (and presumably proteome) is a result of diameter or a genetically controlled phenotype because guard hairs in sheep are typically of very much higher diameter than any wool fibre [29]. However, CTQ contained some guard hairs of similar diameter to underhairs. The result suggests independently patterned hair types in each fleece and that highly differentiated cortical cell types are not purely a consequence of fibre diameter, nor is medullation [31].

Macroscopic observation (Fig. 3) clearly indicates that despite having similar hair types, the fleece of CTQ contains a high level of high-diameter guard hairs and relatively few, and short, underhairs compared to that of SE. At the level of hair structural components within a given volume of wool, this means that CTQ may have a greater proportion of medullary proteins than does SE.

Selection of which proteins to include in the LFQ analysis was based on our understanding of the relationship between fibre morphology and keratin protein content. The process of keratinisation is an example of controlled cell apoptosis that sees the removal of most proteins in the fibre, resulting in the predominance of the keratinous ones [32]. For instance, actin and tubulin, which are present in the developing follicle, are no longer detectable by $2 \mathrm{DE}$ in the keratinised fibre [14]. This is further supported in this study where the major trichocyte keratins and KAPs as identified in other studies ([28, $\underline{33}]$ respectively) have the highest sequence coverage and the non-keratinous proteins have the lowest sequence coverage, these nonkeratinous ones mostly only identified by one peptide.

These results provide further support for the proteomic data, the most significant of which relates to the level of medullation in the three fibre types. In particular, the 
Type II keratin K75, which is found in the medulla of hair fibres [34], is present at a level 24-times higher in CTQ than MB. As MB fibres are known to be largely medulla-free this fold change points to the presence of a considerable amount of medulla in the guard hairs of CTQ. In contrast the 10-times fold change between MB and SE is not significant and this is most probably related to the fact that SE wool is more similar to MB wool than CTQ wool, there being no significant difference in mean fibre diameter between MB and SE wool $(p=.396)$. This is largely because SE wool has fewer guard hairs than CTQ, the latter being almost entirely composed of guard hairs. This suggests that this protein might be good marker for determining the extent of medullation in fibres from sheep.

In contrast to this, $\mathrm{K} 38$, which is also found in the cortex as well as the medulla, is not a good candidate for a marker for the level of medullation in wool. Though the levels of this protein are elevated in CTQ relative to $\mathrm{MB}$ and reduced in $\mathrm{MB}$ relative to SE these fold ratios are not significant ( $p=.131$ and 0.209 respectively). This is probably because this protein is present in lower in abundance in the mature wool fibre compared to K31, K33a, K33b, K34 and K35 (the latter itself being a low abundant keratin) [30] or even in the developing follicle [14].

One other interesting trend in these fibres is the relatively higher amounts of the HGTPs in the MB vs CTQ comparison. HGTPs have been associated with orthocortex $[\underline{35}, \underline{36}]$. This may suggest higher levels of orthocortex in MB wool. There is a general rule, supported by data that the proportion of orthocortex within wool fibres increases, concurrently with a decrease in paracortex, as the fibre diameter increases, but that there is also a significant amount of inter-individual and inter-breed variation in the relationship [22,30]. The current view, informed by studies of higher diameter wools, non-ovine hairs and lustre mutant sheep $[\underline{16}, \underline{28}, \underline{37}, \underline{38}]$ is that the division of cortical cell types (strictly into orthocortex, mesocortex and paracortex) is a somewhat simplistic division and that ortho- and para-cortical cell architecture are two extremes in what is actually a progressives shift between them [28]. It is this view that allows us to identify that CTQ high-diameter wool fibres are unusual because of the almost binary highly differentiated orthocortex and paracortex they contain (as opposed to a gradually differentiated orthocortex and paracortex normally associated with highdiameter fibres). What this means for the proteome-structure relationship is unclear. The levels of abundance of the HGTPs between MB and SE were quite similar, 
despite the higher fibre diameter of the underhairs of SE, once again despite the difference in diameter between MB and SE. Like the earlier study [28] differences in protein up and down regulation observed in this study reinforces the idea that the proteome-structure relationship (and mechanomics) of mammalian hair fibre is complex. CTQ underhairs may be a useful model system contributing to further investigation in investigating this difficult area.

One unintended consequence of this study is the potential of the LFQ approach to differentiate between different breeds of sheep. While the LFQ results for these breeds of wool have not been validated by another method, the relative abundances of the proteins and their relationship to internal fibre morphology are consistent with what has been observed in other studies [28, $\underline{39]}$. Though the sample size had been limited to only five animals per breed and no attempt was made to separate the guard hairs from the underhairs (wool), partial discrimination of the three breeds proved possible (Fig. 6). The MB breed was distinguishable from SE and CTQ, the overlap between the latter two possibly being due to the small number of animals used or the presence of smaller amounts of guard hairs mixed in with the finer fibres of the SE breed.

\section{Acknowledgements}

Authors are grateful to Mr. Tiago Perloiro (ANCORME - Merino Breeders Association, Évora, Portugal) and Mr. João Madanelo (ANCOSE - Serra da Estrela Breeders Association, Oliveira do Hospital, Portugal) for kindly supplying respectively the MS and SE wool samples. Authors acknowledge the artwork by Mr. Simão Mateus (Lourinhã Museum, Lourinhã, Portugal) used in Fig. 1 and the graphical abstract, and for helpful discussions with Evelyne Maes and Alasdair Noble. Funding for this project was provided by the Ministry of Business, Innovation and Employment of New Zealand (Contract number: C10X0710) and AgResearch Strategic Science Investment Funding (A19115). Author AM Almeida acknowledges funding from unit program LEAF - Linking Landscape, Environment, Agriculture And Food Research Centre (ISA - University of Lisbon) funded by the FCT (Fundação para a Ciência e a Tecnologia) strategic project (UID/AGR/04129) for Research infrastructure. Authors AM Almeida, A Campos and J Plowman were members of COST actions FA1002 - Proteomics in Farm Animals to whom 
networking funding is acknowledged. The funding Agencies of this study had no role in the design of the study, data collection and analysis, interpretation of data, the decision to submit the report for publication or preparation of the manuscript.

\section{Appendix A. Supplementary data}

Download all supplementary files included with this article

Help

Download : Download Comma Separated Value file (168KB)

Proteomics identification and quantitation data

Download : Download spreadsheet (44KB)

Individual Protein abundances per sample

Download : Download spreadsheet (29KB)

Proteomics statistical analysis table

\section{References}

$[1]$

International wool textile Organization

https://www.iwto.org/wool-production (2020)

[2]

M. Naval-Sanchez, Q. Nguyen, S. McWilliam, L.R. Porto-

Neto, R. Tellam, T. Vuocolo, A. Reverter, M. Perez-

Enciso, R. Brauning, S. Clarke, A. McCulloch, W. Zamani, S. Naderi, H.R. Rezaei, F. Pompanon, P. T aberlet, K.C. Worley, R.A. Gibbs, D.M. Muzny, S.N. Jhangiani, N. Cockett, H. Daetwyler, J. Kijas

Sheep genome functional annotation reveals proximal regulatory elements contributed to the evolution of modern breeds

Nat Commun., 9 (2018), p. 859

View Record in Scopus Google Scholar

[3]

M.L. Ryder

The evolution of the fleece 
Sci. Am., 257 (1987), pp. 112-119

CrossRefView Record in ScopusGoogle Scholar

$[4]$

C.A.P. Matos

Animal genetic resources and traditional production systems in Portugal

Archivos de Zootecnia, 49 (2000), pp. 363-383

View Record in ScopusGoogle Scholar

[5]

J. Plowman, A. Thomas, T. Perloiro, S. Clerens, A.M. de Almeida

Characterisation of white and black merino wools: a proteomics study

Animal, 13 (2019), pp. 659-665

ArticleDownload PDF $\underline{\text { CrossRefView Record in ScopusGoogle Scholar }}$

[6]

A.M. Almeida, A. Bassols, E. Bendixen, M. Bhide, F. Ceciliani, S. Cristobal, P.D. Eckersall, K. Hollun g, F. Lisacek, G. Mazzucchelli, M. McLaughlin, I. Miller, J.

Nally JE, J. Plowman, J. Renaut, P. Rodrigues, P. Roncada, J. Staric, R. Turk

Animal board invited review: advances in proteomics for animal and food sciences

Animal, 9 (2015), pp. 1-17

ArticleDownload PDFView Record in ScopusGoogle Scholar

[7]

R. Soares, C. Franco, E. Pires, M. Ventosa, R. Palhinhas, K. Koci, A. Martinho de Almeida, A. Varela Coelho

Mass spectrometry and animal science: protein identification strategies and particularities of farm animal species

J Proteomics, 75 (2012), pp. 4190-4206

ArticleDownload PDFView Record in ScopusGoogle Scholar

[8]

G. Paredi, S. Raboni, E. Bendixen, A.M. de Almeida, A. Mozzarelli

"Muscle to meat" molecular events and technological transformations: the proteomics insight J. Proteome, 75 (2012), pp. 4275-4289

ArticleDownload PDFView Record in ScopusGoogle Scholar 
I. Marcelino, A.M. de

Almeida, C. Brito, D.F. Meyer, M. Barreto, C. Sheikboudou, C.F. Franco, D. Martinez, T. Lefrançois , N. Vachiéry, M.J. Carrondo, A.V. Coelho, P.M. Alves

Proteomic analyses of Ehrlichia ruminantium highlight differential expression of MAP1-family proteins

Vet. Microbiol., 156 (2012), pp. 305-314

ArticleDownload PDFView Record in ScopusGoogle Scholar

L.E. Hernández-

Castellano, A.M. Ferreira, P. Nanni, J. Grossmann, A. Argüello, J. Capote, G. Cai, J. Lippolis, N. Cas tro, A.M. de Almeida

The goat (Capra hircus) mammary gland secretory tissue proteome as influenced by weight loss: a study using label free proteomics

J. Proteome, 145 (2016), pp. 60-69

\section{ArticleDownload PDFView Record in ScopusGoogle Scholar}

J.E. Plowman, W.G. Bryson, T.W. Jordan

Application of proteomics for determining protein markers for wool quality traits Electrophoresis, 21 (2000), pp. 1899-1906

View Record in ScopusGoogle Scholar

H. Koehn, S. Clerens, S. Deb-Choudhury, J.D. Morton, J.M. Dyer, J.E. Plowman

The proteome of the wool cuticle

J. Proteome Res., 9 (2010), pp. 2920-2928

CrossRefView Record in ScopusGoogle Scholar

A.M. Almeida, J.E. Plowman, D.P. Harland, A. Thomas, T. Kilminster, T. Scanlon, J. Milton, J. Gree

$\mathrm{ff}, \mathrm{C}$. Oldham, S. Clerens

Influence of feed restriction on the wool proteome: a combined iTRAQ and fiber structural study

J. Proteome, 103 (2014), pp. 170-177 
J.E. Plowman, D.P. Harland, S. Ganeshan, J.L. Woods, B. van Shaijik, S. DebChoudhury, A. Thomas, S. Clerens, D.R. Scobie

The proteomics of wool fibre morphogenesis

J. Struct. Biol., 191 (2015), pp. 341-351

$\underline{\text { ArticleDownload PDFView Record in ScopusGoogle Scholar }}$

J.E. Plowman, S. Deb-Choudhury, S. Clerens, A. Thomas, C.D. Cornellison, J.M. Dyer

Unravelling the proteome of wool: towards markers of wool quality traits

J. Proteome, 75 (2012), pp. 4315-4324

ArticleDownload PDFView Record in ScopusGoogle Scholar

A. Thomas, D.P. Harland, S. Clerens, S. Deb-

Choudhury, J.A. Vernon, G.L. Krsinic, R.J. Walls, C.D. Cornellison, J.E. Plowman, J.M. Dyer

Interspecies comparison of morphology, ultrastructure, and proteome of mammalian keratin fibers of similar diameter

J. Agric. Food Chem., 60 (2012)

$2434-2346$

$\underline{\text { Google Scholar }}$

Y. Li, G. Zhou, R. Zhang, J. Guo, C. Li, G. Martin, Y. Chen, X. Wang 
Comparative proteomic analyses using iTRAQ-labeling provides insights into fiber diversity in sheep and goats

J. Proteome, 172 (2018), pp. 82-88

$\underline{\text { ArticleDownload PDFCrossRefView Record in ScopusGoogle Scholar }}$

A. Latosinska, K. Vougas, M. Makridakis, J. Klein, W. Mullen, M. Abbas, K. Stravodimos, I. Katafigi otis, A.S. Merseburger, J. Zoidakis, H. Mischak, A. Vlahou, V. Jankowski

Comparative analysis of label-free and 8-plex iTRAQ approach for quantitative tissue proteomic analysis

PLoS One, 10 (2015), p. e0137048, 10.1371/journal.pone.0137048

CrossRefView Record in ScopusGoogle Scholar

F.B. Shorland, J.M. Gray

The preparation of nutritious protein from wool

British Journal of Nutrition, 24 (1970), p. 717

View Record in ScopusGoogle Scholar

J.N. Gillespie, L.A. Goldsmith

The structural proteins of hair: Isolation, characterization and regulation of biosynthesis

L.A. Goldsmith (Ed.), Biochemistry and Physiology of the Skin, Oxford University

Press, Oxford (1983), pp. 475-510

$\underline{\text { Google Scholar }}$ 
D.P. Harland, J.P. Caldwell, J.L. Woods, R.J. Walls, W.G. Bryson

Arrangement of trichokeratin intermediate filaments and matrix in the cortex of merino wool J. Struct. Biol., 173 (2011), pp. 29-37

$\underline{\text { ArticleDownload PDFView Record in ScopusGoogle Scholar }}$

D.P. Harland, J.P. Vernon, J.L. Woods, S. Nagase, T. Itou, K. Koike, D.R. Scobie, A.J. Grosvenor, J. M. Dyer, S. Clerens

Intrinsic curvature in wool fibres is determined by the relative length of orthocortical and paracortical cells

J Exp Biol., 22 (2018)

221(Pt 6)

$\underline{\text { Google Scholar }}$

J.E. Plowman

Diversity of trichocyte keratins and keratin-associated proteins (KAPs)

J.E. Plowman, S. Deb-Choudhury, D.P. Harland (Eds.), Hair Keratins. Structure, Assembly and Development, Springer, Singapore (2018), pp. 21-32

CrossRefView Record in ScopusGoogle Scholar

S.D. Bringans, J.E. Plowman, J.M. Dyer, S. Clerens, J.A. Vernon, W.G. Bryson

Characterisation of the exocuticle a-layer proteins of wool

Exp. Dermatol., 16 (2007), pp. 951-960

CrossRefView Record in ScopusGoogle Scholar 
A. Nesvizhskii, R. Aebersold

Interpretation of shotgun proteomic data: the protein interference problem

Mol. Cell. Proteomics, 4 (2005), pp. 1419-1440

ArticleDownload PDFView Record in ScopusGoogle Scholar

R.D.B. Fraser, D.A.D. Parry

Structural hierarchy of trichocyte keratin intermediate filaments

J.E. Plowman, S. Deb-choudhury, D.P. Harland (Eds.), Hair Keratins. Structure, Assembly and

Development, Springer, Singapore (2018), pp. 57-70

CrossRefView Record in ScopusGoogle Scholar

R.D.B. Fraser, D.A.D. Parry

Trichocyte keratin-associated proteins (KAPs)

J.E. Plowman, S. Deb-Choudhury, D.P. Harland (Eds.), Hair Keratins. Structure, Assembly and Development, Singapore, Springer (2018), pp. 71-86

CrossRefView Record in ScopusGoogle Scholar

J.E. Plowman, D.P. Harland, D.R. Scobie, D. O'Connell, A. Thomas, P.H. Brorens, M. Richena, E. M eenken, A.J. Phillips, J.A. Vernon, S. Clerens

Differences between ultrastructure and protein composition in straight hair fibres

Zoology, 133 (2019), pp. 40-53

ArticleDownload PDFView Record in ScopusGoogle Scholar 
D. Harland, J. Woods, J. Vernon, R. Walls, D. Scobie, J. Plowman, C. Cornellison, T. Craven, T. Itou , K. Koike, S. Nagase, S. Clerens, J. Dyer

Like follicle, like fibre?Diameter and not follicle type correlates with fibre ultrastructure

Key Engineering Materials, 671 (2015), pp. 88-94

View Record in ScopusGoogle Scholar

D.F.G. Orwin, J.L. Woods, S.L. Ranford

Cortical cell types and their distribution in wool fibres

Australian Journal of Biological Science, 37 (1984), pp. 237-255

View Record in Scopus Google Scholar

D.R. Scobie, A.R. Bray, N.C. Merrick

Medullation and average fibre diameter vary independently in the wool of Romney sheep

N. Z. J. Agric. Res., 41 (1998), pp. 101-110

CrossRefView Record in ScopusGoogle Scholar

D.P. Harland, J.E. Plowman

Development of hair fibres

J.E. Plowman, S. Deb-choudhury, D.P. Harland (Eds.), Hair Keratins. Structure, Assembly and Development, Springer, Singapore (2018), pp. 109-154

CrossRefView Record in ScopusGoogle Scholar 
S. Deb-Choudhury, S. Plowman, A. Thomas, G.L. Krsinic, J.M. Dyer, S. Clerens

Electrophoretic mapping of highly homologous keratins: a novel marker peptide approach

Electrophoresis, 31 (2010), pp. 2894-2902

CrossRefView Record in ScopusGoogle Scholar

L. Langbein, H. Yoshida, H. Praetzel-Wunder, D.A. Parry, J. Schweizer

The keratins of the human beard hair medulla: the riddle in the middle

J. Investig. Dermatol., 130 (2010), pp. 55-73

ArticleDownload PDFCrossRefView Record in ScopusGoogle Scholar

Z. Yu, G. Gordon, A.J. Nixon, C.S. Bawden, M.A. Rogers, J.E. Wildermoth, N.J. Maqbool, A.J. Pears on

Expression patterns of keratin intermediate filament and keratin associated protein genes in wool follicles

Differentiation, 77 (2009), pp. 307-316

ArticleDownload PDFView Record in ScopusGoogle Scholar

B.C. Powell, A. Nesci, G.E. Rogers

Regulation of keratin gene expression in hair follicle differentiation

Ann. N. Y. Acad. Sci., 642 (1991), pp. 1-20

View Record in ScopusGoogle Scholar 
J.L. Woods, D.P. Harland, J.A. Vernon, G.L. Krsinic, R.J. Walls

Morphology and ultrastructure of antler velvet hair and body hair from red deer (Cervus elaphus)

J. Morphol., 272 (2011), pp. 34-49

CrossRefView Record in ScopusGoogle Scholar

D.P. Harland, R.J. Walls, J.A. Vernon, J.M. Dyer, J.L. Woods, F. Bell

Three-dimensional architecture of macrofibrils in the human scalp hair cortex

J. Struct. Biol., 185 (2014), pp. 397-404

ArticleDownload PDFView Record in ScopusGoogle Scholar

F. Li, H.S. Ouyang, G.E. Rogers, C.S. Bawden

Characterization of the structural and molecular defects in fibres and follicles of the felting lustre mutant

Exp. Dermatol., 18 (2009), pp. 134-142

ArticleDownload PDFView Record in ScopusGoogle Scholar 